\title{
Empirical Research on the Effectiveness of MOOCs in Developing Design Students on Sino-foreign Cooperation University Programs
}

\author{
http://dx.doi.org/10.3991/ijet.v11i06.5304 \\ Zhu Tiejun \\ Anhui Polytechnic University, Wuhu, China
}

\begin{abstract}
Nowadays, the implementation of Sino-foreign cooperative education program has become an essential way to internationalize Chinese higher education.The large number of MOOC online resources currently available, and their innovative teaching modes has provided a new and novel channel to promote such programs. In order to systematically illustrate and reveal the effectiveness of utilizing MOOC in these projects, which sponsored by Undergraduate cooperative education project of visual communication design between Anhui Polytechnic University and University of Bridgeport, researchers carried out a one-year targeted and systematic tracking, investigation, comparative analysis, consultation, summary and the real-time assessment. Experimental data and detailed research results show that the MOOC intervention mechanism achieved a positive effect in promoting and supplementing students' knowledge and understanding of their major. It not only strengthened students' skills and literacy, it was also found to significantly promote traditional classroom teaching at Anhui Polytechnic University. The project proved successful with design students by combining in class and online teaching. It is recommended that such projects be further promoted and applied in the future.
\end{abstract}

Index Terms-Design Students, Effectiveness of MOOCs, Empirical Research, Sino-foreign Cooperation University Program

\section{INTRODUCTION}

"A MOOC (massive open online course) is an online course with the option of free and open registration, a publicly shared curriculum, and open-ended outcome."[1] In recent years the concept of massive open online course (MOOC) has been developing rapidly. It is being applied throughout the whole field of higher education. "There has also been speculation o $\mathrm{n}$ their potential as a 'disruptive' educational platform, which will force re-thinking and re-structuring of existing educational models."'[2] "MOOC was born only a few years, but it has led to a 'digital tsunami' in the field of global education." [3]

In China, "MOOC as a new form of courses has acquired wide praise in Chinese high education field because of its novel learning approach, teaching method and learning freedom. MOOC has also attracted a number of enterprises to invest and construct the platform for meeting the top teachers and cultivating excellent students in the worldwide.'[4]Many colleges and universities have joined the international MOOC platform, furthermore, some well-knownuniversities have started to build their own platforms for the MOOC, and set up a large number of Chinese MOOCs. "'MOOCs' rapid development makes higher education move forward, many colleges and universities are scrambling to join the 'MOOCs' is an example.’[5]

As an important part of the Chinese education internationalization strategy, Sino-foreign cooperation university programs between universities are not new. Over the past few years, it has rapidly developed and received extensive attention. Various colleges and universities are further promoting the internationalization of education and students development through a great variety of Sinoforeign cooperation university programs.

In 2014, Anhui Polytechnic University (AHPU) held the Visual Communication Design Undergraduate Education program (VCDUE program) with University of Bridgeport (UB) of the United States.

The program aims to develop specialized graduates who have a global view of design and can understand the characteristics of Chinese design culture in order to adapt to the design demand in digital era. It is hoped to unite traditional design skills with the modern digital media technology. To achieve this goal, Anhui Polytechnic University utilizes this Sino-foreign cooperation university program as an experimental item which exploratively draws domestic and foreign MOOCs into the whole students' development scheme, so as to advocate and encourage teachers and students to actively participate in and construct MOOCs auxiliary teaching system. During this one-year experiment, researchers have applied earlyterm guide, mid-term evaluation and late-term summary real-time model to track, inquire, and assess the effectiveness of MOOCS intervention mechanism.

"The open property of MOOC constructs and shows its unique creation, structure and operation, which provides a special way of thinking for the development of traditional university curriculum, teaching organization and operation." [6]This paper makes full use of this special way of thinking to analyze MOOC operating path and the feedback on design Sino-foreign cooperation university programs. The goal of this research study is to synthesize the advantages of MOOCs and Sino-foreign cooperation university programs, and to utilize solid empirical research to demonstrate the effect of MOOCs intervention mechanism for the promotion of the quality of students' cultivation in design Sino-foreign cooperation university programs. This paper hopes to provide inspiration and reference for other Sino-foreign cooperation university programs in China, and to popularize this successful case which is based on MOOCs online and offline mixed teaching model and students' cultivation model. 
PAPER

EMPIRICAL RESEARCH ON THE EFFECTIVENESS OF MOOCS IN DEVELOPING DESIGN STUDENTS ON SINO-FOREIGN...

\section{BACKGROUND}

Until September 2014 Chinese official statistics show that "Sino-foreign cooperation university programs have reached the number of 2056. This involves nearly 600 Chinese universities and more than 400 foreign universities, 33 countries and regions, and nearly 55 million Chinese students." It is undeniable that China has now become the world's largest cross-border education resource country.

The intention and purpose of the Chinese Ministry of Education is to vigorously promote Sino-foreign cooperation university programs and to encourage domestic universities to introduce high quality educational resources from abroad. In this way, participants can not only absorb, learn and draw from advanced international education ideas, but can also make it possible for them to cultivate all kinds of elites needed for the future development of China. Furthermore, through the online platform, MOOCs' birth and global blooming has opened a learning portal for Chinese universities and their students so that they can learn about and be exposed to a vast range of international resources. Additionally, most of these resources are free from top universities and teachers. Therefore, MOOCs provide a new opportunity to enhance the effective implementation of Sino-foreign cooperation university programs.

MOOCs have several advantages. Firstly, they present the culmination of many years of teachers' experience and knowledge. Secondly, hey utilize innovative education ideas and techniques. Thirdly, their modules are interest based. It can be called "quality + innovation + efficient " education resource. This effect is fully consistent with the purpose of holding Sino-foreign cooperation university programs, which attracts first-class international educational resources and highly efficiently cultivates innovative international compound talents by using innovative teaching mode. This has and will have a profound influence on Chinese universities, and their students and teachers. MOOCs forcefully became the catalyst to enhance and deepen Sino-foreign cooperation university programs.

\section{MOOCS INTERVENTION MECHANISM IN DEVEloping Design STUdENTS ON SinO-ForEIGN CoOperation Education Program BeTweEn AHPU} AND UB

\section{A. Purpose}

As a local engineering university in central China, AHPU has its own distinctive features of design within Anhui province, however, international art and design resources are relatively deficient and weak, compared to developed provinces in China. Nowadays, contemporary international compound design talents need to have a global vision, a broad knowledge base, be able to think innovatively and have a unique perspective of their field. In addition, they required to have excellect practice skills and rich experience in design. This means any cooperative education program should "adhere to introduce diversification of foreign high-quality educational resources ". [8] It is impossible that AHPU fully depends on the resources of UB, therefore, as a new type of high quality education platform, MOOC has become an important supplementary resource to such Sino-foreign cooperation education programs. In addition, "the art design specialties Sino-foreign cooperation programs are relatively rare, and the experiences worth of learning are limited". [9] Furthermore, the art design specialties Sinoforeign cooperation programs with MOOCs mechanism are even rarer.

The VCDUE program held by AHPU and UB in 2014 is not only the first design specialty Sino-foreign cooperation education program, but it represents a breakthrough in Sino-foreign cooperation education program at AHPU. As a consequence, AHPU plans to implement it as an excellent project and a demonstration project. Due to the reasons above, AHPU has greatly supported the management of the program through the construction of software and hardware facilities as well as teachers allocation. It has also carefully planned many aspects of training programs and the curriculum. Apart from these measures, AHPU has also utilized wide resources and treated this program as an experimental unit to actively introduce and recommend MOOC online platform to effectively complement and expand international resources. As well as to deeply promote wide- ranging knowledge and skills acquirement by the students who undertake this visual communication design undergraduate program.

\section{B. MOOCs recommendation}

The basic form of the VCDUE program between AHPU and UB is " $2+2$ ". This means that students of this program study in AHPU for the first 2 years and complete the remaining 2 years study at UB. How do these freshmen reach the appropriate English level, professional standards as well as the psychological state to study abroad and get a degree after only 2 years? This is a huge challenge to them, and it is also a scientific and effective comprehensive assessment about the professional training and students' development system of this program. In order to reduce the barriers in the students training process of Sino-foreign cooperation education program, AHPU introduces selected MOOC courses to students. MOOC resources are mainly derived from the collaborative University's online courses and the Chinese MOOC education platform such as NetEase open courses, Sina open courses, Sohu online education, China online resources, National Excellent courses, Icourse and CCTV open courses. It also focuses on overseas recourses including Coursera, EdX, Udacity, Ted. The range of MOOCs and other online resources are huge and extensive. Students can participate in the study according to their own needs, however, the Arts College which manages this program has also developed a selective scheme. According to the students' training goals and orientation of this program, the administrative team has assembled highly skilled professional teachers to select a total of 197 key recommended free MOOCs that involve general education courses, discipline professional courses, practical education courses and comprehensive education courses. For example, general education courses mainly include college mathematics, scientific exploration, and classic literature and so on; Discipline professional courses involve typographic design, illustration design, motion graphic etc.; Color sketch, photography etc. belong to practical education courses; courses such as creative methodology, International understanding education are part of comprehensive education category. 
PAPER

EMPIRICAL RESEARCH ON THE EFFECTIVENESS OF MOOCS IN DEVELOPING DESIGN STUDENTS ON SINO-FOREIGN...

TABLE I.

ClassificATION OF MOOCS RECOMMENDATION

\begin{tabular}{|c|c|c|c|c|c|}
\hline \multirow[b]{2}{*}{ Item } & \multicolumn{3}{|c|}{ General Education } & \multicolumn{2}{|c|}{ Discipline professional course } \\
\hline & $\begin{array}{c}\text { Humanities and social } \\
\text { sciences }\end{array}$ & \multicolumn{2}{|c|}{ Nature science } & Professional basic course & Professional core course \\
\hline The number of course subjects & 50 & & & 30 & 30 \\
\hline Among: English language & 32 & & & 17 & 18 \\
\hline Among: Chinese language & 18 & & & 13 & 12 \\
\hline \multirow{2}{*}{ Item } & \multicolumn{4}{|c|}{ Practical education } & \multirow{2}{*}{ Comprehensive education } \\
\hline & \multicolumn{2}{|c|}{ Basic education practice course } & \multicolumn{2}{|c|}{ Professional education practice course } & \\
\hline The number of course subjects & \multicolumn{2}{|l|}{7} & \multicolumn{2}{|r|}{10} & 30 \\
\hline Among: English language & \multicolumn{2}{|l|}{4} & \multicolumn{2}{|r|}{6} & 22 \\
\hline Among: Chinese language & \multicolumn{2}{|l|}{3} & \multicolumn{2}{|r|}{4} & 8 \\
\hline
\end{tabular}

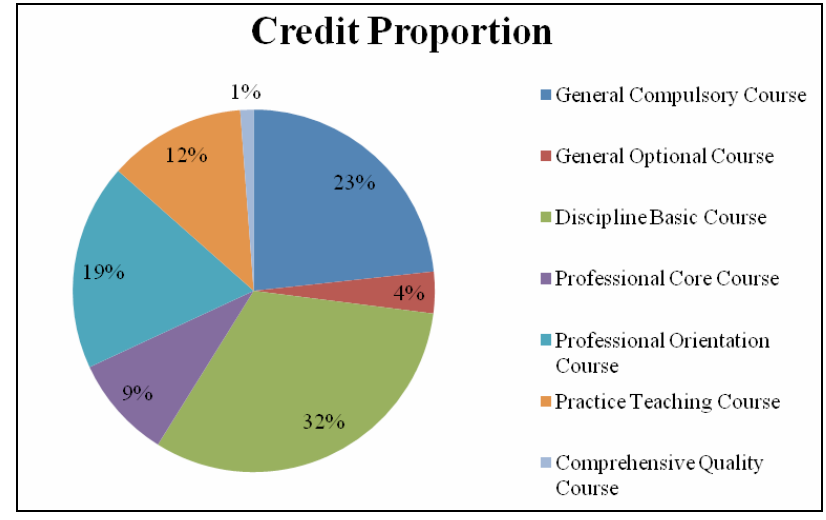

Figure 1. The credit proportion of various types of courses in the program training scheme

\section{EMPIRICAL ANALYSIS ON THE EFFECTIVENESS OF MoOCs}

The freshmen of this program enrolled in September 2014. The total number was 39. By the end of August 2015, all students had successfully completed one year of the MOOCs intervention learning process. This research analysis shows the effectiveness of MOOC through diverse investigations, comparisons and evaluations.

\section{A. Early-term guide and investigation}

Investigation and statistics of student enrollment status: It is necessary to scientifically evaluate the practical effectiveness of MOOC in the training process of this program and comprehensively investigate student enrollment status. The investigation and statistics took all the 39 students as objects. The statistical content involves students' age, sex, place of birth, entrance exam total score, English score, interests and hobbies, experience and purpose of going abroad, the situation of owning electronic learning tools.

TABLE II.

\begin{tabular}{|c|c|c|c|c|c|}
\hline $\begin{array}{c}\text { Student } \\
\text { number }\end{array}$ & Male & Female & Urban & Rural & $\begin{array}{c}\text { Average } \\
\text { Entrance } \\
\text { ExamScore }\end{array}$ \\
\hline 39 & 22 & 17 & 25 & 14 & 728.82 \\
\hline $\begin{array}{c}\text { Average Entrance } \\
\text { English Score }\end{array}$ & $\begin{array}{c}\text { The number of } \\
\text { people who have } \\
\text { been abroad }\end{array}$ & $\begin{array}{c}\text { Owned computer and } \\
\text { other electronic learn- } \\
\text { ing appliances }\end{array}$ \\
\hline \multicolumn{2}{|c|}{67.63} & 3 & \multicolumn{2}{|c|}{$100 \%$} \\
\hline
\end{tabular}

Depending on the results of the statistics, urban area students account for $64.1 \%$, and the rest $35.9 \%$ are from rural areas. Entrance exam total scores showed a big gap, with 36 points between the highest and the lowest score. Their English scores did no differ greatly, but their overall English level was not high. Only 3 people had visited other countries. One of them was for a short-term studying tour and the other two were for tourism. All the students have laptops and smart phones and other electronic products or equipment.

Questionnaire of MOOC intervention mechanism: In order to know teachers and students' attitude, thoughts and the value of the expectation for MOOC intervention mechanism, researchers applied a professional English survey website: www.surveymonkey.com to make two copies of questionnaire for students and teachers respectively at the beginning of the first term. All 39 students completed the questionnaire. A total of 27 Chinese teachers, teaching staff and administrative staff involved in the program were given a different questionaire to complete.

The questionnaire for students had 20 questions: Item 1 to 3 comprised basic information about the student; 4 to 8 inquired as to students have experienced MOOCs or similar extent to MOOCs; 9 to 12 asked them about their attitude and ideas towards the program;13 to 17 are MOOCs categories which students are likely to choose in the future and the number of these MOOCs and studying weeks; 18 to 20 were related to current status assessment by the students themselves, the problems which they encountered in studying, cause analysis and results predict.

The questionnaire for teachers and administrators involved a total of 17 questions: Item 1 to 5 were basic information; 6 to 9 inquired as to their understanding of MOOCs; 10 to 14 inquired into what effect and influence could have on their regular teaching as well as their attitudes and views to MOOC intervention mechanism; 15 to 17 let them to anticipate on and speculate the possible effectiveness of students' utilizing of MOOCs.

Questionnaire analysis: The questionnaire for student shows $66.67 \%$ of the students had never heard of MOOC, 25.64\% had heard of MOOC but knew very little. Only $7.69 \%$ can describe the related concepts and significance of MOOC; All students were willing to try MOOC and showed great interest in it; nearly $2 / 3$ (23 students) were keen on choosing humanities, social science, innovative thinking and creative design courses. More than 1/5 (9 students) thought that professional orientation courses are more important. The remaining 
students expressed that they did not possess clear objectives; 36 students have an ambivalent feeling on studying English MOOCs, and all the students worried as to whether they could adapt to English MOOCs because of their current low level of English. However, as the same time they indicated their optimism and confidence in using MOOC and were hopeful of the benefits which MOOC may bring.

Another questionnaire showed that all the teachers and administrators knew MOOC well, but it was clear that only 7 people knew how to make their own MOOC. 19 questionnaire copies admitted that MOOCs mode has given a strong impact on current higher education system and colleges teachers. 15 respondents felt that MOOC intervention mechanism of this program would bring a huge challenge to teachers, and 23 respondents approved the program because they believed it would greatly assist their regular teaching and improve their effectiveness.

\section{B. Mid-term teaching information collection and MOOCs learning tracking assessment}

Daily classroom teaching information and data collection: By the end of the first half academic year, researchers did an assessment of the preliminary effectiveness of the MOOC learning. There were 18 teaching weeks in the first semester, researchers randomly chose one course each week to collect and recorded the detailed teaching and studying state. Based on these data, researchers analyzed the effectiveness and change of daily classroom teaching activities which were reflected by students.

Table III shows whether it is from the student's attendance rate change, or the frequency of interaction in class discussions increases, it demonstrates that teachers and students have a sharp change in teaching activities due to MOOC intervention. Because curiosity and thirst for knowledge of students were relatively strong when they just started their new studying life in the university and experienced university courses. The attendance rate was high, whereas the interaction and reaction between teachers and students were low. The teacher's teaching methods were relatively simple, mostly they were few opportunities for interactive discussions and communication. As the subject of classroom teaching, "students have a deep feeling on teachers' teaching attitude, teaching level, before and after correlation of teaching content ". [10] In the middle of the academic year, students had learned some MOOCs and even the same MOOC as current regular course. Because many MOOCs were from top universities and used innovative teaching methods, as a result students felt a certain gap between expectation and practical learning in some courses. Satisfaction in traditional classroom is also gradually reduced, for this reason, the attendance rate decreased. However, the frequency of interaction in class discussions, teacher questioning rate and student speech time were higher than earlier. In the final 6 teaching weeks, students' attendance rate rose again and other indicators reached their peak. This phenomenon on the one hand revealed that teachers had taken certain measures to improve their classroom teaching effectiveness after they paid attention to students' change. On the other hand, it also reflects the students' flipped classroom needs, their ambitions to achieve winning, and their sense of competiveness. In this situation, the significance of attending the class is not only to learn, but also is to "debate", to "argue", and to "discourse". Students' learning initiative and flexibility significantly increased.

Mid-term questionnaire: The mid-term evaluation also used questionnaire, but this time, it selected the teachers and staff groups who were direct observer and intimate contactor of students as the object of the survey. The questionnaire had 19 questions: Item 1 to 3 were respondents' basic information; 4 to 5 referred to students confidence; 6 to 8 involved students learning initiative, autonomy and changes of their interests; 9 to 10 investigate students studying communication situation after class; 11 to 12 inquired into students' thinking ways and their research ability after MOOCs studying; 13 to 14 surveyed the excellent rate of completing various of learning tasks by students; 15 to 17 were the extent of English level improvement; 18 to 19 inquired performance status about students teamwork, communication and practice ability.

According to the results of questionnaire, through the intuitive perception and evaluation of teachers observing student's performance in class and after class and participation in all sorts of activities, the students have improved to some degree after MOOCs implementation. This improvement was seen in their learning initiative, learning autonomy, learning confidence, English level, thinking depth and breadth, excellent rate of completing learning tasks, inquiring and communication frequency between teachers and students after class, practice ability, team cooperation and communication ability and other aspects. A group of data is showed in Figure 2. It is evident that MOOCs auxiliary teaching mode has exerted an influence at several levels of student development.

TABLE III.

Key Daily Classroom Teaching Information And Data Collection Of The First Semester (Above Data Is An AVERage Value For EVERY 6 TEACHING WEEKS)

\begin{tabular}{|c|c|c|c|c|}
\hline Teaching Week & Attendance\% & $\begin{array}{c}\text { The frequency of interaction } \\
\text { in class discussions }\end{array}$ & Teacher questioning rate & Student questioning rate \\
\hline $1-6$ & $96.15 \%$ & 2.17 & 5.17 & 2.17 \\
\hline $7-12$ & $91.88 \%$ & 3.83 & 7.33 & 5.17 \\
\hline $13-18$ & $95.73 \%$ & 5.17 & 11.83 & 9.5 \\
\hline Teaching Week & Students' speech frequency & $\begin{array}{c}\text { Teaching methods using of } \\
\text { each class }\end{array}$ & Teachers' satisfaction rate of students' answer \\
\hline $1-6$ & 6.33 & 2 & $55.56 \%$ \\
\hline $7-12$ & 11.67 & 2.5 & $76.47 \%$ \\
\hline $13-18$ & 18.17 & 3.83 & $89.29 \%$ \\
\hline
\end{tabular}




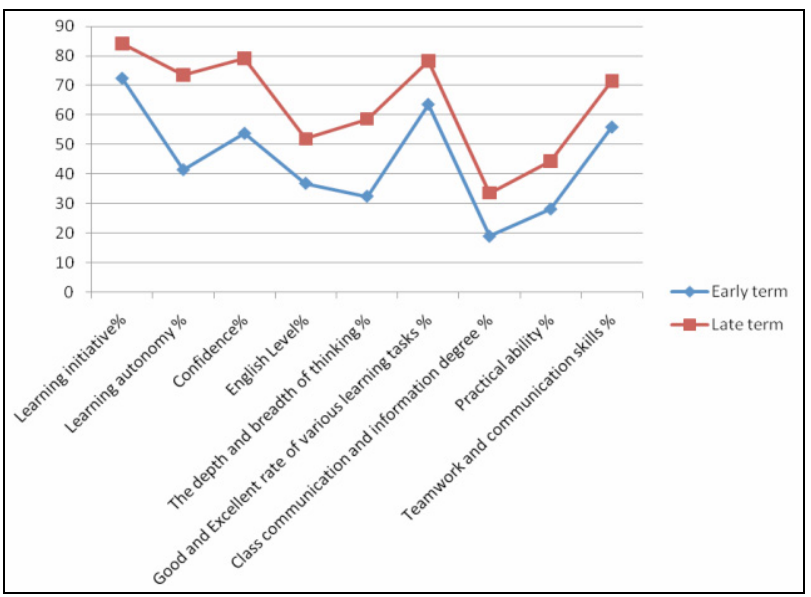

Figure 2. Effectiveness on students MOOCs learning Mid-term teacher questionnaire results analysis

The interview of some students MOOC learning: In a semester MOOC class experience learning process, the researchers used a sampling tracking mode survey: according to the real-time understanding of 2 boys and 2 girls, a total of 4 who were interviewed have completed at least 1 English and 1 Chinese MOOCs. The main contents of the interview and the results were summarized in Table IV and Table V. In addition, the researchers also organized two theme class meeting activities, inviting some teachers and students to share their experiences in using MOOCs, gathering information and giving guidance and advice to students as well.

Mid-term tracking assessment for MOOCs effectiveness analysis: Based on 3 levels of summation namely the information collection through daily classroom interaction, the questionnaire and the tracking interview, three major observations were made, it was seen that the classroom environment, teachers' teaching and students' learning were gradually changing because of the effectiveness of MOOCs. The complementary nature of in class and online learning has improved activity within the classroom as well as the quality and effectiveness of classroom teaching. The degree of tacit understanding increased constantly as well. The simple stage of teachers' teaching and students' learning has changed into the stage of promotion each other. Some courses with active interaction have even become flipped classroom.

Secondly, after the students learned MOOCs, their inside and outside classroom performances had improved earning their teachers' praise, because "MOOCs are not just to teach, but also to engage."[11] At the same time, it is generally believed that the students have a good view of their autonomous learning. Their high autonomous learning ability makes teachers' guidance easier and smoother. Students choose courses in MOOCs study according to their own learning abilities and interests, to a certain extent, which formed the relative balance of their learning level. Teachers can also well balance on teaching contents and teaching method due to MOOCs intervening. As a result, it is easy to organize discussion and interaction in class.

Thirdly, students experienced the differences and uniqueness of the MOOCs mode, and could orientate their individual learning levels and interests, and preliminary judge the advantages and bottlenecks of learning MOOCs in accordance with their individual characteristics. At the same time, their abilities and skills, which are reflected in autonomous learning, solving problems, sharing, case analysis and teamwork were improved as well. All the students reported a strong interest to keep using MOOCs.

TABLE IV.

THE INTERVIEW OF PARTS OF STUDENTS MOOC LEARNING RECORD

\begin{tabular}{|c|c|c|c|c|c|c|}
\hline Interview student & $\begin{array}{c}\text { Learning } \\
\text { course } \\
\text { number }\end{array}$ & $\begin{array}{c}\text { English } \\
\text { course diffi- } \\
\text { culty degree }\end{array}$ & $\begin{array}{c}\text { Tendency } \\
\text { course teaching } \\
\text { weeks }\end{array}$ & Tendency course type & $\begin{array}{c}\text { Recommended } \\
\text { courses to other } \\
\text { students or not }\end{array}$ \\
\hline Male student 1 & 2 & Very difficult & Within 5 weeks & $\begin{array}{c}\text { Science and technology } \\
\text { activities }\end{array}$ & Course community communication & No \\
\hline Female student 1 & 3 & Difficult & $6-8$ weeks & Sports and art activities & Quiz \\
\hline Male student 2 & 3 & Very difficult & Within 5 weeks & Design services & Mutual evaluation of students & Yes \\
\hline Female student 2 & 3 & Very difficult & Within 5 weeks & $\begin{array}{c}\text { Humanities and Social Sci- } \\
\text { ences }\end{array}$ & Yes \\
\hline
\end{tabular}

TABLE V.

THE INTERVIEW OF PARTS OF STUDENTS MOOC LEARNING RECORD

(*) NUMERICAL 1-10 RESPECTIVELY CORRESPOND TO LOW LEVEL INTEREST TO HIGH LEVEL INTEREST.

\begin{tabular}{|c|c|c|c|c|c|}
\hline $\begin{array}{c}\text { Interview } \\
\text { Student }\end{array}$ & $\begin{array}{c}\text { The biggest advantage of } \\
\text { MOOC study }\end{array}$ & $\begin{array}{c}\text { The biggest gain of } \\
\text { MOOC study }\end{array}$ & $\begin{array}{c}\text { The biggest difficulty of } \\
\text { MOOC study }\end{array}$ & $\begin{array}{c}\text { Self-solving strategies for } \\
\text { the biggest problem }\end{array}$ & $\begin{array}{c}\text { Interest rate } \\
\text { of continue } \\
\text { learning }(*)\end{array}$ \\
\hline Male student 1 & Low learning threshold & $\begin{array}{c}\text { Enhance innovation } \\
\text { consciousness }\end{array}$ & English language barrier & No countermeasures & 7 \\
\hline Female student 1 & No time and space limit & Improve English Level & Cultural thinking obstacles & Culture transposition thinking & 9 \\
\hline Male student 2 & Abundant course recourses & $\begin{array}{c}\text { Strengthen autonomous } \\
\text { learning }\end{array}$ & Big knowledge span & Expand the reading surface & 7 \\
\hline Female student 2 & Excellent Course explanation & Broaden knowledge & English language barrier & Repetitive learning & 8 \\
\hline
\end{tabular}


PAPER

EMPIRICAL RESEARCH ON THE EFFECTIVENESS OF MOOCS IN DEVELOPING DESIGN STUDENTS ON SINO-FOREIGN...

TABLE VI.

One YeAr MOOCs LEARning NumBer, COMPLETIOn RATE AND Dropout RATE Statistics

\begin{tabular}{|c|c|c|c|c|c|c|c|c|}
\hline \multirow{2}{*}{ Item } & \multicolumn{2}{|c|}{ General Education } & \multicolumn{2}{|c|}{ Discipline subject } & \multicolumn{2}{c|}{ Practical education } & \multicolumn{2}{c|}{ Comprehensive education } \\
\cline { 2 - 10 } & English & Chinese & English & Chinese & English & Chinese & English & Chinese \\
\hline Averagenumber of elective courses & 1.92 & 1.67 & 1.69 & 1.13 & 0.64 & 0.31 & 1.23 & 1.33 \\
\hline Course completion rate\% & 53.33 & 61.54 & 45.45 & 61.36 & 72 & 75 & 39.58 & 53.85 \\
\hline Course dropout rate $\%$ & 46.67 & 38.46 & 54.55 & 38.64 & 36 & 25 & 60.42 & 46.15 \\
\hline
\end{tabular}

\section{Late-term feedback, data comparison and analysis, MOOC effectiveness summary and induction}

MOOCs completion rate and dropout rate statistics: By the end of the first academic year, the researchers had collected data, which included the number of MOOC courses each student chose, completed and dropped out during an academic year. Statistical situation shows as Table VI.

Feedback questionnaire: The questionnaire was a comprehensive survey and feedback of all the VCDUE program students' learning for one year of taking part in MOOCs mode. There were 33 questions which covered three major categories, involving comprehensive information about the student selecting MOOCs, student overall perception to MOOC intervention mechanism, and student comprehensive evaluation of MOOCs learning effectiveness. Item 1 to 3 were student personal information; 4 to 12 were the sources and acquired channel of selected MOOCs, types, English language courses number, Chinese language courses number, and average courses teaching weeks, the number of simultaneous registrations and the reasons for selection. Questions 13 to 17 inquired about the number of students who completed MOOCs and also those who dropped out MOOCs and the reasons as well. 18 to 25 focused on collecting students' feedback comments and sub-item assessment such as the impact on the daily teaching activities and students' comprehensive skills and abilities development due to MOOC intervention mechanism; From 26 to 31 investigated the effect, problems, causes and solutions in the actual MOOCs learning process; From 32 to 35 surveyed the feeling and harvest of students learning MOOCs, at the same time inquired their opinion and willing in formally introducing MOOCs mode into students learning evaluation system.

Results analysis: There is a certain deviation between actual data of MOOCs categories and the expected value which showed on the first questionnaire, the number of MOOCs learning, learning weeks and expected value of the first early-term questionnaire. It was seen that the actual average is less than the expected average value. One possible reason for this was the initial lack of understanding of MOOCs which meant they made casual choices in early-term. But in late-term, they had grasped MOOCs learning methods and were able to make more realistic and appropriate choices. Only then were they capable of treating MOOC intervention mechanism more rationally and objectively. Although students selected and orientated accurate more than the previous, however, their cautious psychology enhanced, it produced the above deviation.

The proportion of students selecting MOOCs for personal interest accounts for $38.46 \%$, among which $20.51 \%$ chose English language MOOCs because they hoped to understand, feel and adapt to the foreign classroom teaching and learn English. 25.64\% expected to develop skills and expand their knowledge to enhance their future employment prospects. It has been studied "MOOCs help expand their personal networks, and facilitate their career development."[12]Other reasons such as recommended by classmates to study using MOOCs, dissatisfaction with the daily classroom teaching, needing make-up study, psychological drive in being a follower accounts for the rest of $15.38 \%$.

The main reasons for students dropping out were due to failure to effectively understand the course content, the deviation between learning content and personal interest, failure to complete the whole course, feeling course useless and so on. After a year of MOOCs learning, 35 students totally agreed to introduce MOOCs into this program, but 4 of them were undecided.

$23.08 \%$ of students considered that the MOOC intervention mechanism produced a significant impact on both individual comprehensive cultivation and the whole daily teaching activities. $61.54 \%$ expressed that MOOC intervention mechanism caused remarkable changes in some specific aspects, such as classroom teaching activity, students' learning autonomy, students' confidence, the improvement of English level, the expansion of knowledge, innovative thinking and cooperative awareness training and so on, and the remaining $15.38 \%$ felt that a certain effectiveness and influence, but was not little significance.

Regarding the shortcomings of MOOC intervention mechanism and their learning problems, 35.9\% of students pointed out MOOCs did not provide an adequate opportunity to practical work and failed to effectively meet the actual professional design training. $28.21 \%$ of the students thought that this program introduced the MOOCs, but it was not incorporated into the formal program teaching management system. MOOCs achievement recognition was not very high to a certain extent, which affected its further development. 25.64\% find MOOCs were rich in resources, but the course form was single, the model was more formalized, and the level of teaching objectives unclear. Thus, it was difficult to meet the specific requirements of small groups, and further limits parts of its utility. $10.26 \%$ of the students suggested that the program should increase the combination and linkage of online and offline resources between daily teaching and MOOCs. They also put forward the suggestion that a specific teacher be appointed to resolve English MOOCs learning and English language issues.

$82.05 \%$ of the students who studied MOOCs for a year expressed pleasure in doing so; $76.92 \%$ of the respondents pointed out MOOCs learning brought them great benefits; Regarding to formally recognize MOOCs scores and integrate it into the students learning evaluation system, $20.51 \%$ of the students strongly advised program management team to implement it immediately, $46.15 \%$ agree with this point, $17.95 \%$ have no clear opinion, $15.38 \%$ oppose its implementation. 
PAPER

EMPIRICAL RESEARCH ON THE EFFECTIVENESS OF MOOCS IN DEVELOPING DESIGN STUDENTS ON SINO-FOREIGN...

TABLE VII.

All Sorts Of Awards And Participating In Events Data Statistics Of Sino-Foreign CoOperation Class And Paralleled Regular CLASS

\begin{tabular}{|c|c|c|c|c|}
\hline Item & $\begin{array}{c}\text { University level awards } \\
\text { (person-time) }\end{array}$ & $\begin{array}{c}\text { Municipal awards } \\
\text { (person-time) }\end{array}$ & $\begin{array}{c}\text { Provincial awards } \\
\text { (person-time) }\end{array}$ & $\begin{array}{c}\text { National awards } \\
\text { (person-time) }\end{array}$ \\
\hline Regular Class & 5 & 2 & 1 & 0 \\
\hline Sino-foreign cooperation Class & 9 & 5 & 2 & 1 \\
\hline Item & $\begin{array}{l}\text { Above the Municipal lev- } \\
\text { el(Including) Competition } \\
\text { attendance (person-time) }\end{array}$ & $\begin{array}{l}\text { Above the Municipal lev- } \\
\text { el(Including) recreational and sports } \\
\text { activities attendance (person-time) }\end{array}$ & $\begin{array}{c}\text { All sorts of academic } \\
\text { activities } \\
\text { (person-time) }\end{array}$ & $\begin{array}{l}\text { The number of } \\
\text { individual and } \\
\text { collective honor }\end{array}$ \\
\hline Regular Class & 78 & 132 & 159 & 11 \\
\hline Sino-foreign cooperation Class & 112 & 156 & 285 & 17 \\
\hline
\end{tabular}

Statistical analysis of the Sino-foreign cooperation class compared with a paralleled regular class: To compare, test and analyze the real effectiveness of this program, based on a year tracking record, the researchers selected a regular class of the same grade, specialty and the similar students' number (40 students) as a compared object. They then collected average GPA data of courses like Basic English, design basic courses and professional basic courses, data of winning various awards and participating in competitive events. They also specially organized twice TOEFL (IBT) English simulation test to Sinoforeign cooperation class respectively in the first semester and the second semester. Now relevant statistics are as shown in Figure 3.

Data comparison analysis: Compared to the Sinoforeign cooperation class, the regular class did not implement MOOCs intervention mechanism. Management department had neither made a clear guidance on MOOCs learning, nor recommended MOOCs to regular class students at the beginning of the term and the whole year. Around the above data analysis can be drawn:

Table VI showed that the dropout rate of MOOCs was high. According to the further analysis of the segmentation data, freshmen's MOOCs learning number, completion rate and dropout rate were all different according to specific time frames in the academic year. In the early-term period, the higher excitement of learning new matter and meeting new things meant a higher participation and completion rate of MOOCs. This tendency decreased slightly in mid-term. In the third term, the number of elective MOOCs tended to be stable, but the dropout rate was higher than before. Relevant international MOOC dropout rate research results showed "although there are tens of thousands of people registered for the course, but the actual completion rate of the majority of the course is less than 13\%". [13] In this case, there was no such high dropout rate as the international statistics, but it could be seen that students MOOCs learning existed obvious instability and randomness. It was difficult for students to guarantee self-discipline. There were four main reasons:

Firstly, program management did not set up the specific requirements, like mandatory assessment tasks or penalty system, and MOOCs learning recognition mechanism. Therefore, once students met problems such as learning difficulties, inconsistent interest, they easily gave up learning.

Secondly, the randomness and unlimited learning time led to some students to use fragment time to learn, learning stability and efficiency were not guaranteed.
Thirdly, MOOCs are based on the "stimulus-response" mode. When do the students summarize and assess their achievement? How to digest and absorb this knowledge? What are the actual results and the quality of learning? There is no such a set of effective evaluation criteria.

Finally, MOOCs learning mostly happens in students' spare time. An inadequate study environment meant that some students were easily distracted, thus making it difficult for them to concentrate on virtual online courses.

By comprehensively contrasting the Sino-foreign cooperation class with the regular class average GPA data in Figure 3, researchers discovered that the English level of Sino-foreign cooperation class was significantly higher than that of regular class. This was due to the English courses strengthened, introduction of original teaching textbooks from the United States and foreign teachers, as well as the introduction of the recommended MOOCs (especially English language MOOCs). The average GPA of basic English course of Sino-foreign cooperation class was 0.75 point (out of 4.0) more than regular class ; Regarding design basic courses, as these courses were the focus of study in their first year to systematically master professional knowledge, techniques, skills and methods, both classes of students work hard. For this reason, design basic courses average GPA of regular class without introducing MOOC mechanism was close to Sino-foreign cooperation class. Modeling foundation course average GPA was higher than the Sino-foreign cooperation class by 0.06 ; Professional basic courses focused on mastering basic professional theoretical knowledge. Although it belonged to emphatic learning object, such courses related to a large discipline field and wide comprehensive knowledge range. Due to the abundant resources, extensive learning contents and diverse selection ways of MOOCs, the Sino- foreign cooperation class which brought in MOOC mechanism showed the relative advantages, especially two courses average GPA of visual communication design introduction, design thinking and method were 0.44 and 0.42 higher than regular class respectively.

Data statistics results of Table VII on various awards and participating in competitions of Sino-foreign cooperation class and paralleled regular class coincide with researchers' previous anticipation: the statistical figure of Sino-foreign cooperation class is significantly higher than the regular class. Although there are no obvious differences between design basic courses and professional basic courses in the first academic year guiding specialty training plan, the strong involvement of MOOCs and combination of the UB curriculum system strengthen Sino-foreign 
PAPER

EMPIRICAL RESEARCH ON THE EFFECTIVENESS OF MOOCS IN DEVELOPING DESIGN STUDENTS ON SINO-FOREIGN...

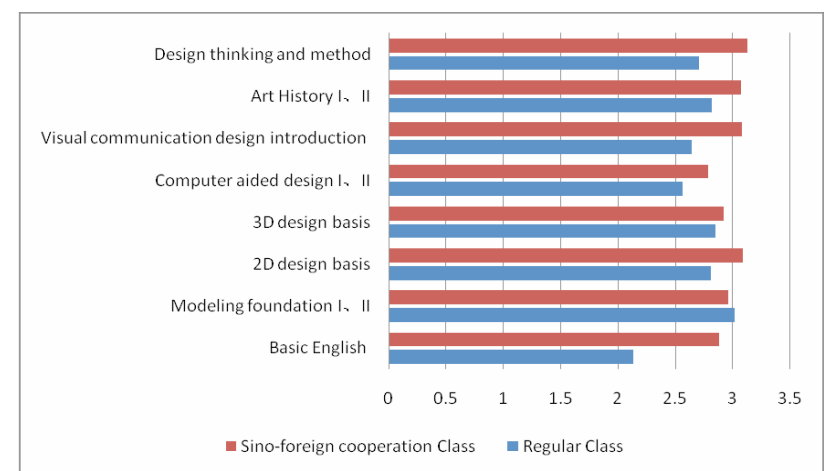

Figure 3. Basic English, design basic courses and professional basic courses average GPA data statistics of Sino-foreign cooperation class and paralleled regular class

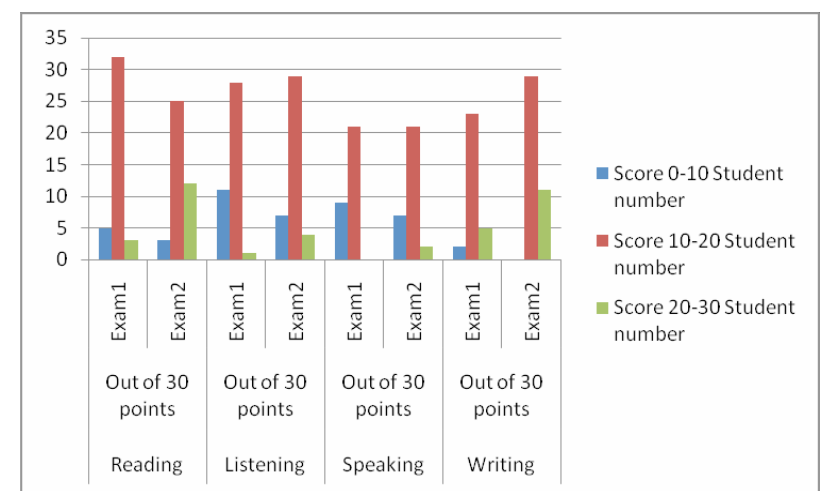

Figure 4. Sino-foreign cooperation class twice new TOEFL English simulation test results

cooperation class students in terms of students' learning autonomy, confidence, adaptability, broaden their vision, open their mind, diversify their knowledge, enhance their teamwork awareness and innovation quality. Thus, all kinds of awards, related competition achievements, students' initiative and enthusiasm are better than those of regular class.

In Figure 4, Sino-foreign cooperation class two new TOEFL English simulation test scores are distinct. The English level of the second semester in the first academic year of Sino- foreign cooperation class has been significantly improved. Admittedly, this achievement is partly attributed to the United States textbooks, teachers, teaching concepts and methods introduction and the increase of English courses. According to the whole process MOOCs effectiveness research, students all give an affirmation to English ability improvement and overseas life and learning way adaption which are caused by MOOCs introduction and MOOCs learning. "In China, the overall English level of students who study in the discipline of art is low. Due to most of MOOCS using English, students will improve their English level by studying MOOCS". [14]Therefore, the successful model of this VCDUE program integrated with English MOOCs should be spread further.

\section{CONCLUSION}

Focusing on the effectiveness of MOOC in developing design students on visual communication design Sinoforeign cooperation education program between AHPU and UB and based on one academic year empirical re- search, researchers reached and obtained the following conclusions:

During MOOCs learning period, program students obviously felt the differences and uniqueness of the MOOCs teaching in the learning and experience process. They were able to identify their own learning level, interests, as well as find out and make a preliminarily judgment of the advantages, problems and solve countermeasures of learning MOOCs in accordance with their own characteristics. It was found that qualities and abilities of autonomous learning, confidence, adaptability, vision, English level, cooperative and innovative spirit were improved.

MOOCs intervention mechanism of this program significantly promoted traditional classroom teaching. Not only the students' classroom activities and interactive communications were frequent, but also the teacher's guidance, inquiry and feedback became very smooth and in-depth. In addition, due to MOOCs intervention mechanism, students' comprehensive abilities and diverse knowledge were improved. Their learning requirements became more and more strong. The phenomenon of flipped classroom was more and more frequent. This situation prompted teachers to profoundly rethink, keep learning and do their best to teach. They should be also familiar with curriculum systems and course knowledge structures, improve their diverse knowledge and skills, and continue to broaden, learn and create teaching methods and teaching mode to easily control over flipped classroom. Therefore, MOOC intervention mechanism in this program actually brought an online and offline mixed teaching mode and the change of students developing model. It further triggered an inward sense of extraordinary innovative effectiveness.

A few students in MOOCs learning appear two different extreme phenomena - anxiousness caused by big problems beyond their present situation and excessive reliance on MOOCs. There also exist the drawbacks of MOOCs asynchronous communication teaching model, lack of practice courses resources and late-term increased MOOCs dropout rate etc. To tackle these problems, the following recommendations are made: (1) Program management should increase daily teaching and MOOCs online and offline resources linkage and integration. (2)They should also emphasize timely guidance, special counseling and the importance of solving individual student problems, do "real-time detection of dissatisfied students"[15], (3)introduce early warning mechanism, (4)and simultaneously cooperatively implement the appointment of individual teacher tutorial mechanism, (5) organize similar or different types of MOOCs learning seminars, (6)carry out experience sharing theme activities, (7)build real-time data feedback mechanism for teachers to collect students MOOCs selection and completion information, (8)construct teacher self-development MOOCs encouraging mechanism to effectively avoid the negative factors of MOOCs learning and to realize the maximization of effectiveness of MOOCs.

MOOC intervention mechanism in students' developing of this program achieved a positive effect. Combined with the practical significance of the case study and empirical conclusions, on the one hand, we can appropriately promote and spread this successful experience in a wider range. On the other hand, we will continue to deepen the integration of MOOCs with the regular teaching system in design-oriented Sino-foreign cooperation education pro- 
PAPER

EMPIRICAL RESEARCH ON THE EFFECTIVENESS OF MOOCS IN DEVELOPING DESIGN STUDENTS ON SINO-FOREIGN...

grams, and incorporate MOOCs learning recognition into the student comprehensive evaluation system at the right time, so as to expand its practical effectiveness and application prospect.

\section{REFERENCES}

[1] Chen, Y. (2014). Investigating MOOCs through blog mining. The International Review of Research in Open and Distributed Learning, 2015.2:85-106.

[2] Conole, G. (2013). MOOCs as Disruptive Technologies: Strategies For Enhancing The Learner Experience and Quality of MOOCs, Network. Journal of Distance Education, no. 39, September - December, 2013, pp. $1-17$.

[3] He Bin, MOOC: Essence, Current Situation and Prospect[J], Jiangsu Education Research, 2014.1 : 3-7.

[4] Gong Xuemei,Chen Zhen,Zhang Xinguang, Present Situation and Development Prospects for Application of MOOCs in Higher Education $[\mathrm{J}]$, Journal of Ningbo University of Technology, 2014.3 : 100-105.

[5] Guo Yingjian, MOOCs in the world: Its status dilemma and future[J], Journal of Higher education management, 2014.4: 41-48.

[6] China Education Network -- 2013 MOOC white paper [M]. Beijing: Beijing newspapers issued, 2013: 13.

[7] Zhang Wenling, China has become the world's largest cross-border education resource country [N], the China Youth Daily, 2015-0509:02.)

[8] Yan Xiao, Influence factors and basic principles of Sino-foreign cooperation running programs on introduction of foreign highquality educational resources, Jiangsu higher education $[\mathrm{J}]$, 2014.1:120-122155.

[9] Zhang Zongdeng, Zhang Hongying, Liu Zhi, Art design specialty Sino-foreign cooperation running programs existing problems and countermeasures[J], design, 2014.1:155-156.

[10] Zong Ping, Research on teaching quality guarantee mechanism of Sino-foreign cooperation running programs [J], Jiangsu higher education, 2015.1:76-78.
[11] Hamish Macleod, Jeff Haywood, Amy Woodgate, Emerging patterns in MOOCs: Learners, course designs and directions, echTrends, January/February 2015 Volume 59, Number 1:56-63.

[12] Tawanna Dillahunt, Zengguang Wang, Stephanie D. Teasley, Democratizing Higher Education: Exploring MOOC Use Among Those Who Cannot Afford a Formal Education, The International review of research in open and distance learning, Vol 15 , No 5,2014 Nov: 177-195.

[13] D.F.O.Onah, J.Sinclair, R.Boyatt (2014), Dropout Rates of Massive Open Online Courses: Behavioural Patterns. In Proceedings of the 6th International Conference on Education and New Learning TechnologiDULEARN1BarcelonaSpain7th-9th July2014

[14] Gulnara SadykovaMediating Knowledge through Peer-to-Peer Interaction in a 1ulticultural 11ine Leaming Enviralment: A Case Study of Interactional Students in the USle Interactional review of research in open and distance learining Vol 15No 3 July/142449

[15] Vatted Abeer Barliria Students' preferalces and views about leaming in a MOOCProcedia - Social and Behavioral Scialces 152 (2014) $318-323$

\section{AUTHORS}

Zhu Tiejun is with the Art College, Anhui Polytechnic University, Wuhu City, Anhui Province, 241000 P. R. China (e-mail: ztj@ahpu.edu.cn)

This work was supported by 2016 Anhui province university outstanding young talent fund key project (GXYQZD2016117); "International compound students training mode of Local colleges and universities in global MOOCs era" (2014jyxm43); "Sino-foreign cooperation University programs and international application oriented innovative students training mode" (2013jyxm103); "Art major practical teaching small-semester mode construction and implementation" (2012jyxm276); "Anhui Polytechnic University international developing strategy research (2015gjzd010) ". Submitted, 22 Novernber 2015. Published as resubmitted by the authors on 15 April 2016. 